\title{
Measured effects of provocation and emotional mastery techniques in fostering emotional intelligence among Nigerian adolescents
}

\section{Ajibola Olusoga Ogunyemi}

Department of Educational Foundations and Counselling,

Olabisi Onabanjo University, Ago, Iwoye

\section{Nigeria}

jibolaogunyemi@yahoo.com 


\begin{abstract}
Introduction. This study investigated the effects of provocation and emotional mastery programmes at fostering emotional intelligence of Nigerian adolescents. The study also aimed to establish whether gender will moderate the effects of the two techniques on emotional intelligence skills of adolescents.
\end{abstract}

Method. The study employed a pretest-post-test control group design using a 3 x 2 factorial matrix. The simple random sampling procedure was used in selecting participants and assigning them to two treatments groups and the control group. A total of 270 participants taken among senior secondary school students in three randomly selected public secondary schools participated in the study. Data were collected using the Emotional Intelligence Scale (EIS). Analysis of covariance (ANCOVA) was employed for data analysis with significant level fixed at 0.05 .

Results. Findings from the study revealed that the treatments differentially and significantly affect participants' levels of emotional intelligence. Gender, as well as gender and treatment were found not to have any significant effects on participants' levels of emotional intelligence.

Discussion. On the basis of the findings, the study advocated for the integration of emotional intelligence as school subject in secondary school curricular.

Keywords: provocation, emotional mastery, emotional intelligence, adolescents 


\section{Resumen}

Introducción. Este trabajo investigó los efectos de programas de provocación y dominio emocional en el estímulo de la inteligencia emocional de adolescentes nigerianos. Otro objetivo fue establecer si el género modera los efectos de las dos técnicas sobre habilidades de inteligencia emocional de los adolescentes.

Método. Se empleó un diseño de grupo control con pretest y post-test, con una matriz factorial de $3 \times 2$. El procedimiento de muestro aleatorio simple se utilizó para seleccionar los participantes y asignarles a dos groups de tratamiento y un grupo control. Participaron en el estudio un total de 270 estudiantes del último ciclo de educación secundaria, procedentes de tres institutos de secundaria también seleccionados aleatoriamente. Se recogieron datos a través de la Emotional Intelligence Scale (EIS) [Escala de Inteligencia Emocional]. Se empleó un análisis de covarianza (ANCOVA) para analizar los datos, con nivel de significación fijado en 0,05 .

Resultados. Los hallazgos del estudio revelan que los tratamientos afectan el nivel de inteligencia emocional de los participantes de forma diferencial y significativa. Género, igual que género juntamente con el tratamiento, no demostró tener ningún efecto significativo sobre el nivel de inteligencia emocional de los participantes.

Discusión. Los hallazgos sugieren la conveniencia de la integración de la inteligencia emocional como asignatura dentro del currículo de la educación secundaria.

Palabras clave: provocación, dominio emocional, inteligencia emocional, adolescentes

Recibido: 02/07/07 Aceptación Provisional: 27/04/08 Aceptación Definitiva: 29/05/08 


\section{Introduction}

Over the years, in Western thought, emotion has taken a back seat to cognition, being considered by scholars as inferior to reason, primarily because emotion might work against reason to bias accurate judgement and decision making (Mayer, Salovey \& Caruso, 2000). In recent times, there is growing recognition of the key role that emotions play in our lives. We are gradually realising the limit of our minds and the need to balance intellect with feeling and emotion. The accumulating body of evidence from research on emotion has increasingly indicated that affective phenomenon constitute a unique source of information which informs thoughts, actions and subsequent feelings (see Salovey, Bedell, Detweiler \& Mayer, 2000).

The rapid changes and the growing complexity of life changes have made understanding and mastery of the emotions increasingly important. Strong negative emotions such as fear, worry, distress and anger if not properly managed, can be injurious to health. In order to avoid the damaging effects of emotions, and to harness the creative potential in effective use of the emotions, it is important that one is emotionally intelligent. According to Castella (2001), "What really matters for success character, happiness and the life long achievement is a definable set of emotional skills..." (p. 29). Leaders in the workplace or school, and outstanding performers are not defined or known by their intelligent quotients (I.Q) or even their job skills, but by their emotional intelligence (Yong, 2001). Many studies have proved that factors such as intellectual intelligence, levels of competence, and technological support are not enough to ensure success in one's endeavour (Echeveria, 1997; Parker, et al 2004; Parker, Summerfeldt, Hogan \& Majeski, 2003; Sosik \& Megerian, 1999; Mayer \& Salovey, 1997; Ransdell, 2001). Managers of men who are merely cognitively intelligence or technologically qualified are less successful than those with certain non-cognitive abilities and traits. These people have the seemingly natural ability to manage their emotions, and manage challenging difficult situations.

It is a truism that academic degrees and other documentation of accomplishments provide access to employment. However, they are significant only at the job offer and its acceptance. Interpersonal and other social skills are keys that keep one going in the job. To some extent and especially in this part of the world where mediocrity, godfatherism, nepotism and other social vices thrive, it is true that it is who you know that matters. But the key to 
knowing the right person is to know how to network, which again is a pointer to the need for emotional learning skills.

Perhaps it was Goleman (1995) who popularised the construct emotional intelligence, first used by Salovey and Mayer (1990) to describe individuals' ability to perceive, express, use, understand and regulate emotions in oneself and others. It is the capacity to monitor emotions in oneself and others to discriminate among emotions, to understand messages in emotions and to use energy in emotions for person gains and fulfilment. In other words, it is the intelligent use of emotions to make them work for you by using them to help guide your behaviour and thinking in ways that enhance your results. A person needs to be emotionally intelligent and use practical process of renewal to succeed. Emotional intelligence works synergistically with IQ to enhance human performance (Akinboye, 2003). It is what differentiates exceptional from mediocre performance. For most of us, it is little known that these natural skills can be fostered or learnt. A wide range of research findings from the field of psychotherapy (Barlow, 1985); training programmes (Marrow, Jarrett \& Rupiuski, 1981) executive education (Boyatzis, Cowen \& Kolb, 1995); and creativity (Min, Mark-A \& Lius-A, 2000; Akinboye, 2003) all provide evidences for people's ability to improve their social and emotional competence with sustained efforts through systematic programmes of training. Thus, the present study attempts to foster emotional intelligence skills of Nigerian adolescents in public secondary schools through the use of provocation and emotional mastery techniques.

Provocation is a creativity technique developed by Edward de Bono. It is a technique that requires lateral thinking. It is a method of generating ideas by unorthodox or apparently illogical methods. It involves moving our thinking out of the established patterns that we use to solve problems normally. The technique involves making deliberately stupid statements (provocation), in which something we take for granted about the situation is not true. Once we have made a provocative statement, our judgement is then suspended and the statement is used to generate ideas. The assumption of this technique is that statements need to be stupid to shook our minds out of existing ways of thinking. The technique is a challenge to exclusivity, which does not accept status quo and is particularly relevant in those areas which ideas have become obsolete with time.

Emotional mastery which is the second treatment programme used in the present study is about getting our emotions to serve us in getting what we want from life. It requires gaining 
an understanding of how our emotions affect us and how we can use the to improve the quality of our lives. When we misperceive our emotions, we may miss the message that they carry or stuff them down, only for them to emerge stronger later. Due to our lack of emotional understanding, we are often slaves to the particular irks and quirks of emotional whims. We may be either emotionally out of control or control addicts. Emotional mastery is the ability to process our emotions so that their message gets to us, and their energy is used for appropriate action.

Considering the fact that gender may facilitate the influenced of training programme on the emotional intelligence skills of participants, the present study also considers gender as second level independent variable to determine its influence on emotional intelligence skills of adolescents.

\section{Hypotheses}

Three hypotheses were raised and tested with significant level fixed at 0.05:

There will be no significant difference in the effects of provocation and emotional mastery on participants' level of emotional intelligence.

There will be no significant difference effect of gender on participants' level of emotional intelligence emotional mastery on participants' level of emotional intelligence

\section{Method}

\section{Participants and Design}

A $3 \times 2$ factorial design was employed. The various factors are treatments, which exist at three levels (i.e. provocation, emotional mastery and the control group) and gender which was observed at two levels (i.e. male and female). A total of 270 senior secondary school students randomly selected from 3 public secondary schools in Ijebu North Local Government Area of Ogun State participated in the study. Thirty (30) of them each were randomly assigned to the two experimental treatments groups and the control group with regards for gender in each of the sample schools. On the whole, a total of 121 males and 149 females were 
used for the study. The age range of the participants was between 12 and 18 years with the mean age and standard deviation of 16.89 and 1.43 years respectively.

\section{Instrumentation}

The emotional intelligence scale (EIS) developed by Schutte et al (1998) was used in this study to obtain pre-post treatment mean scores. The scale is a unidimensional scale that assesses emotional intelligence through 33-self referencing statements tapping the appraisal and expression of emotions in self and others, emotion perception and regulation in self and others, and emotion utilization. The scale is made up of two sections. Section A contains items to measure the demographic data, while Section B of the scale contains items that assess emotional intelligence level of individual. Subjects are to rate the extent they agree or disagree with each statement on a 5 point likert scaling format ranging from 1 (Strongly disagree) to 5 (Strongly agree). Since (EIS) contains 33 items, the total maximum of score that can be obtained on the scale is $33 \times 5=165$, and the lowest is $33 \times 1=33$.

Of the available measures of EI, the researcher opted for EIS developed by Schuttee et al (1998) for the following reasons: First, the development of the items has a theoretical foundation. It was fashioned after Salovey and Mayer's early work model of emotional intelligence. Second, Schutte and her colleague showed that the scale has sound psychometric properties. They reported that the scale has high internal consistency with Chronbach's alpha $(\alpha)$ ranging from 0.87 to 0.90 and two-week test-retest reliability co-efficient of 0.78 . Third, there is evidence for convergent and divergent validity of the instrument. For instance, the scale has been found to correlate with theoretically related construct such as alexithymia, mood repair, optimism and impulse control (Schutte, 1998). Fourth, the EIS has been used extensively in the southern part of the country with both adults (Ogunyemi, 2004; Adeyemo \& Ogunyemi, 2005) and Secondary School Students (Mabekoje \& Ogunyemi, 2003; Adeyemo, 2005) with Cronbach alpha $(\alpha)$ ranging from 0.72 to 0.93 . Fifth, the scale is one of the most readily available scales of emotional intelligence. And lastly, the content of the scale is culture-free and easy to understand; and found suitable for use with adolescents (Schutte et al, 1998). Some of the items of the scale are "I know when to speak about my personal problems to others", "I find it hard to understand the non-verbal messages of other people", "I like to share my emotions with others", "By looking at their facial expressions, I recognize the emotions people are experiencing", "I know why my emotions change". 


\section{Procedure}

Following the approach granted by the 3 principals of the randomly selected school, the general assembly of the senior secondary school II students (SS 2) was conveyed in each of these schools where the researcher educated the entire students about the benefits to be derived from the programme. Students freely volunteered themselves for the eight-week training of just one-hour weekly per group. Only ninety out of the lot were randomly selected through balloting from each of the three schools with regards for gender. The first meeting with the participants in each of the three schools focused on general introduction, establishment of rapport and administration of the emotional intelligence scale on the participants to collect pretest scores. Then, they balloted for the experimental and the control groups with regards for gender. The two experimental groups (i.e. provocation and emotional mastery groups) in each at the three schools were trained in different skills as highlighted under each group below for eight weeks. The control group in each of the three schools was however, given "placebo". They were taught the Nigeria political history from the military era to date just to keep them on.

The training programme was executed through series of lecturers, focus group discussion, case study analysis and take home assignment. The last session of the training was devoted to administration of the same emotional intelligence scale taken at the first session in order to obtain the posttest scores. Thereafter, profound appreciation was expressed to the participants, and the meeting came to a close. The outlines of the meeting packages at each level of the experimental groups are as follows:

\section{Provocation experimental group}

(i) the meaning, nature and importance of creativity

(ii) the meaning, nature and importance of provocation creativity technique

(iii) methods of provocation creativity technique (e.g. escape, reversal exaggeration, wishful thinking and distortion)

(iv) simulation exercise using each of the provocation techniques/methods in generating new ideas

(v) post test administration and formal closing of the programme 
Emotional mastery experimental group

(i) meaning, nature and importance of emotional mastery

(ii) types of emotion (i.e. fear, anger, sadness and joy) and their contributions to healthy and successful life.

(iii) methods/strategies for regulating emotions (e.g. external regulatory and internal regulatory strategies)

(iv) ways of dealing with negative emotions

(v) using emotions to facilitate thinking

(vi) skills of emotional literacy (e.g. capacity for self-awareness; ability to perceive, identify and express emotion; emotional understanding; emotional management)

(vii) steps to mastering emotions

(viii) simulation exercises using the four major types of emotions to facilitate thinking

(ix) post-test treatment administration and formal closing of the programme

Method of Data Analysis

The Analysis of Covariance (ANCOVA) was employed to analyse the data collected through pre-post test treatment administration.

\section{Results}

\section{Hypothesis One}

There is no significant effect of provocation and emotional mastery on participants' emotional intelligence. 
Table 1. Analysis of Covariance of the main and interaction effects of provocation and emotional mastery and gender on subjects' emotional intelligence

\begin{tabular}{|l|l|l|l|l|l|}
\hline Source & $\begin{array}{l}\text { Type III Sum } \\
\text { of Squares }\end{array}$ & Df & $\begin{array}{l}\text { Mean } \\
\text { Square }\end{array}$ & F & Sig. \\
\hline Corrected Model & $18364.787(\mathrm{a})$ & 6 & 3060.798 & 15.169 & .000 \\
Intercept & 21462.957 & 1 & 21462.957 & 106.371 & .000 \\
preemointel & 12939.822 & 1 & 12939.822 & 64.130 & .000 \\
group & 4469.682 & 2 & 2234.841 & 11.076 & .000 \\
gender & 7.767 & 1 & 7.767 & .038 & .845 \\
group * gender & 162.707 & 2 & 81.354 & .403 & .669 \\
Error & 53066.876 & 263 & 201.775 & & \\
Total & 4200909.000 & 270 & & & \\
Corrected Total & 71431.663 & 269 & & & \\
\hline
\end{tabular}

a $\mathrm{R}$ Squared $=.257($ Adjusted R Squared $=.240)$

The results in Table 1 revealed that there is a significant effect of provocation and emotional mastery on participants' emotional intelligence $\left(F_{(2,263)}=11.076 ; p<.05\right)$. No significant effect of gender on subjects' emotional intelligence was indicated $\left(\mathrm{F}_{(1,263)}=.038 ; \mathrm{p}\right.$ $>.05)$. Also, no interaction effect of treatment and gender was shown $\left(F_{(2,263)}=.403 ; p>.05\right)$.

Table 2. Univariate Analysis of Covariance of the effects of provocation and emotional mastery on subjects' emotional intelligence

\begin{tabular}{|l|l|l|l|l|l|}
\hline & $\begin{array}{l}\text { Sum of } \\
\text { Squares }\end{array}$ & df & $\begin{array}{l}\text { Mean } \\
\text { Square }\end{array}$ & F & Sig. \\
\hline Contrast & 4469.682 & 2 & 2234.841 & 11.076 & .000 \\
Error & 53066.876 & 263 & 201.775 & & \\
\hline
\end{tabular}

The $\mathrm{F}$ tests the effect of group. This test is based on the linearly independent pairwise comparisons among the estimated marginal means. 
The results in Table 2 above revealed that a significant effect of treatment exists in the participants' emotional intelligence. The calculated F Ratio of 11.076 was found to be higher than the critical $\mathrm{F}$ ratio of 3.00 at 2 and 263 degrees of freedom. The null hypothesis of no significant effect of provocation and emotional mastery on participants' emotional intelligence was rejected by this finding. To determine the directions of difference a pairwise comparison was done on the treatment techniques. Results are presented in Table 3 below.

Table 3. Pairwise comparison of the differences in the emotional intelligence of participants in provocation, emotional mastery and control groups

\begin{tabular}{|c|c|c|c|c|c|c|}
\hline (I) group & $(\mathrm{J})$ group & $\begin{array}{l}\text { Mean Dif- } \\
\text { ference (I- } \\
\text { J) }\end{array}$ & $\begin{array}{l}\text { Std. } \\
\text { Error }\end{array}$ & Sig.(a) & $\begin{array}{l}95 \% \\
\text { Interval } \\
\text { ence(a) }\end{array}$ & $\begin{array}{l}\text { Confidence } \\
\text { for Differ- }\end{array}$ \\
\hline & & & & & $\begin{array}{l}\text { Lower } \\
\text { Bound }\end{array}$ & $\begin{array}{l}\text { Upper } \\
\text { Bound }\end{array}$ \\
\hline Provocation & emotional mastery & $-5.302(*)$ & 2.137 & .014 & -9.511 & -1.093 \\
\hline & control & $4.754(*)$ & 2.122 & .026 & .575 & 8.933 \\
\hline emotional mastery & provocation & $5.302(*)$ & 2.137 & .014 & 1.093 & 9.511 \\
\hline & control & $10.056(*)$ & 2.137 & .000 & 5.848 & 14.264 \\
\hline Control & provocation & $-4.754(*)$ & 2.122 & .026 & -8.933 & -.575 \\
\hline & emotional mastery & $-10.056(*)$ & 2.137 & .000 & -14.264 & -5.848 \\
\hline
\end{tabular}

Based on estimated marginal means

* The mean difference is significant at the .05 level.

a Adjustment for multiple comparisons: Least Significant Difference (equivalent to no adjustments).

Results in Table 3 showed that significant difference existed in the emotional intelligence between participants exposed to provocation and those exposed emotional mastery programmes $(\mathrm{MD}=5.302 ; \mathrm{p}<.05)$, between participants exposed to provocation programme and 
those exposed to control $(\mathrm{MD}=4.754 ; \mathrm{p}<.05)$ and also between participants exposed to emotional mastery programme and those exposed to control $(\mathrm{MD}=10.056 ; \mathrm{p}<.05)$.

\section{Hypothesis Two}

There is no significant effect of gender on participants' emotional intelligence.

Table 4.Univariate analysis of covariance of the differences in male and female subjects' emotional intelligence.

\begin{tabular}{|l|l|l|l|l|l|}
\hline & $\begin{array}{l}\text { Sum of } \\
\text { Squares }\end{array}$ & df & $\begin{array}{l}\text { Mean } \\
\text { Square }\end{array}$ & F & Sig. \\
\hline Contrast & 7.767 & 1 & 7.767 & .038 & .845 \\
Error & 53066.876 & 263 & 201.775 & & \\
\hline
\end{tabular}

The $\mathrm{F}$ tests the effect of gender. This test is based on the linearly independent pairwise comparisons among the estimated marginal means.

The results in Table 4 revealed that there is no significant effect of gender on participants' emotional intelligence. The calculated F-Ratio of .038 was found to be lower than critical F-Ratio of 3.84 at 1 and 263 degrees of freedom. The null hypothesis of no significant effect of gender on participants' emotional intelligence was therefore accepted by these findings. This implies that subjects' emotional intelligence is not gender specific.

\section{Hypothesis Three:}

There is no significant interaction effect of treatment and gender on participants' emotional intelligence.

Table 5. Descriptive Statistics of Emotional intelligence Scores of Male and Female Participants In Provocation, Emotional Mastery and Control Groups

\begin{tabular}{|l|l|l|l|l|}
\hline group & gender & Mean & $\begin{array}{l}\text { Std. Er- } \\
\text { ror }\end{array}$ & $\begin{array}{l}\text { 95\% Confidence Inter- } \\
\text { val }\end{array}$ \\
\hline & & & $\begin{array}{l}\text { Lower } \\
\text { Bound }\end{array}$ & $\begin{array}{l}\text { Upper } \\
\text { Bound }\end{array}$ \\
\hline
\end{tabular}




\begin{tabular}{|ll|l|l|l|l|}
\hline provocation & male & $123.398(\mathrm{a})$ & 2.196 & 119.073 & 127.723 \\
& female & $123.610(\mathrm{a})$ & 2.055 & 119.564 & 127.656 \\
emotional mastery & male & $129.554(\mathrm{a})$ & 2.358 & 124.912 & 134.197 \\
& female & $128.057(\mathrm{a})$ & 1.966 & 124.186 & 131.928 \\
control & male & $117.582(\mathrm{a})$ & 2.200 & 113.249 & 121.915 \\
& female & $119.918(\mathrm{a})$ & 2.055 & 115.871 & 123.965 \\
\hline
\end{tabular}

a Covariates appearing in the model are evaluated at the following values: pre-test emotional intelligence $=121.5852$.

The results in Table 1 revealed that there is no significant interaction effect of treatment and gender on participants' emotional intelligence. The calculated F-Ratio of .403 was found to be lower than critical F-Ratio of 3.00 at 2 and 263 degrees of freedom. The results in Table 5 also indicated that there is no significant interaction effect of treatment and gender in the emotional intelligence of participants. Male subjects under the provocation group had a mean score of 123.398 and a standard error of 2.196 compared to those under the emotional mastery group with mean and standard error of 129.554 and 2.358 respectively and those under the control group with mean and standard error of 117.582 and 2.200 respectively. Also female subjects under the provocation group had a mean score of 123.610 and a standard error of 2.055 compared to those under the emotional mastery group with mean and standard error of 128.057 and 1.966 respectively and those under the control group with mean and standard error of 119.918 and 2.055 respectively. The null hypothesis which stated that three is no significant interaction effect of treatment and gender on participants' emotional intelligence was sustained by this finding. The finding implies that treatment would not interfere with gender in fostering emotional intelligence of subjects.

\section{Discussion}

The research outcome revealed that provocation and emotional mastery techniques significantly affect the emotional intelligence levels of participants. The results indicated that the experimental groups that benefited from the training in the two treatment programmes (i.e. provocation and emotional mastery) had significantly higher scores on emotional intelligence 
scale compared with the control group. This indicated that the two treatments programmes had significant effect in fostering emotional intelligence skills of participants, thus establishing their effectiveness in exerting influence on the criterion variable. The results corroborate the research finding of Fischer and Fischer (2003) whose subjects in a study of this nature performed better after receiving treatment programmes similar to the one used in the present study. The finding also supports the assertion of Elder (1997) that if students' emotions should be nurtured in the educational process, it will foster positive reactions of instructional materials.

Although the techniques significantly improved emotional intelligence levels of participants, it is however crystal clear that emotional mastery is the most effective of the techniques at fostering adolescents' emotional intelligence. This finding is in the expected direction. Emotional mastery and emotional intelligence are two related constructs that should influence each other. The skills involve in emotional mastery (emotional literacy, emotional fitness, emotional department and emotional alchemy) are the cornerstones in the development of emotional intelligence; and they are related to the four domains of emotional intelligence (emotional understanding and emotional management) identified by Mayer and Salovey (1997).

The results of no significant gender effect, and 2-way interaction effect of gender and treatment on participants' level of emotional intelligence run contrary to the general expectation, and also contradict research findings from earlier studies (see Sutarso et al, 1996; Tapia, 1999; Tapia \& Marsh, 2001). This disparity in findings might however be a result of the fact that many of the earlier studies on emotional intelligence were not accompanied by empirical studies of this nature. They have been conducted on a theoretical basis (Petrides \& Furnham, 2000). However, the fact that cross-cultural studies of gender difference in intelligent quotient (IQ), which is a related construct to emotional intelligence found fairly consistent gender difference (see Furnham \& Baguma, 1999), the result of the present study concerning gender and emotional intelligence can not be definitive; and it remains to be seen whether it will be replicated. 


\section{Conclusion and Recommendation}

When viewed against the backdrop of the growing complexity of technological development which the world is now, and the condition of the modern day living in Nigeria which is characterized by poor leadership, unemployment, lower salary earnings, corruption, sociopolitical and economic stress, diseases and other various emotional ridden social vices, one will realise the fact that the most valuable resource of government is its inherent intellectual assets which can be exploited through teaching emotional intelligence skills. The government should therefore give emotional learning its rightful place in the secondary school curricular for purposeful education, and by extension societal development. There is dare need to integrate in the school curricular a model of emotional competence that explores the factor and skills that contribute to the development of a mature emotional response that supports an individual's cognitive development.

\section{References}

Akinboye, J.O. (2003). Creativity, Innovation and success. Ibadan: Stirling-Horden Publishers Nigeria Limited.

Barlow, D.H., (Ed) (1985). Clinical handbook of psychological disorders: A step-by-step treatment manual. New York: Guilford press.

Boyatzis, R. E., Cowan, S.S., \& Kolb, D.A. (1995). Innovations in Professional Education: Steps on a Journey to Learning. San Francisco: Jossey-Bass.

Castella, D.N., (2001). Mastering our emotions. The Master Facilitator Journal, 4 (2) 21-24

Elder, C. (1997). Critical thinking: The key to emotional intelligence. Journal of developmental education, 21(1) 40-41.

Fischer, R.G. \& Fischer, J.M. (2003). The development, testing, and evaluation of an emotional intelligence curriculum. Retrieved July 20, 2005 from http://searchERIC. Org/ericdc/ED442571. htm.

Goleman, D., (1995) Emotional Intelligence. New York: Bantam.

Mayer, J. D., \& Salovey, P., (1997). What is Emotional Intelligence? In P. Salovey, \& D.J. Sluyter (eds) Emotional Development and Emotional intelligence. Basic Books. New York. 
Mayer, J. D., Salovey, P. \& Caruso, D.R. (2000). Emotional Intelligence as Zeitgeist, and personality, and as a mental ability. In R. Bar-On \& J.D.A. Parkers (Eds), Handbook of Emotional Intelligence (pp. 92-117). San Francisco: Jossey-Bass

Min B., Mark, A. R, \& Luis A. V (2000) .Understanding how creativity thinking skills, attitudes and behaviours work together: A causal process model. Journal of creative behaviour, 34 (2), 77-100

Parker, J.D.A, Summerfeldt, L.J., Hogan, M.J., \& Majeski, S.A., (2004). Emotional Intelligence and Academic Success: Examining the transition from high School to University. Journal of Personality and Individual Differences, 36 (1) 163-172. Elsevier Ltd.

Petrides, K.V., \& Furnham, A., (2000). On the dimensional structure of emotional intelligence. Personality and individual differences, 29, 313 -320.

Ransdell, S., (2001). Predicting college success: The importance of ability and non-cognitive variable. International journal of educational Research, 35, 357-364.

Salovey, P., and Mayer, J., (1990), "Emotional intelligence”, Imagination, Cognition and personality, 9, 185-211.

Salovey, P.; Bedell, B. T.; Detweiler, J.B. \& Mayer, J.D. (2000). Current Directions in Emotional Intelligence Research. In M. Lewis \& J.M. Haviland-Jones (Eds). Handbook of emotions (2nd-ed; pp 504-520) New York: Guilford.

Sosik, J., \& Megerian, J., (1999) "Understanding leader emotional intelligence and performance" Group and organisation Management, 23, 387-91.

Sutarso, T. et al, (1996). Effect of gender and G.P.A on emotional intelligence. Paper presented at the annual meeting of the Mid-south educational research association (Tuscaloosa, AL, November 1996). Retrieved July 27 $7^{\text {th }}, 2005$ from http://search ERIC. org/ericdb/ED 406410. htm

Tapia, M. \& Marsh, E. (2001). Emotional intelligence: The effect of gender, GPA and ethnicity. Paper presented at the annual meeting of the MID-south educational research association $\left(30^{\text {th }}\right.$, Little Rock, AR, November 14-16)

Tapia, M. (1999). The relationships of the Emotional intelligence inventory. Paper presented at the annual meeting of the Mid-south educational research association (point clear, AL, November 16-19).

Yong, L.M. (2001). Emotional Intelligence (EQ) for innovative teamwork and corporate transformation. A paper presented at the RAYMA Management Consultant organized workshop on April 25-26, 2001 at Easton Hotel, Petaling-Jaya, Malaysia. 